JURNAL PANGAN DAN GIZI 9 (1): 74-82, April 2019

ISSN 2086-6429 (Online)

Tersedia online di http://jurnal.unimus.ac.id/index.php/JPDG

\title{
Karakteristik Minuman Ready to Drink dengan Variasi Konsentrasi CMC dan Rasio Kacang Tunggak dan Kacang Hijau
}

\section{Characteristics of Ready to Drink with Variations in CMC Concentration and Ratio of Cowpea and Green Beans}

Tala Desicha Amalia Mukmina, Ratih Lido Prameswari, Relita Indar Hapsari, Iffah Muflihati, Arief Rakhman Affandi

\author{
Program Studi Teknologi Pangan, Fakultas Teknik dan Informatika, Universitas PGRI \\ Semarang \\ Jl. Sidodadi Timur No. 24/Dr. Cipto Semarang \\ taladesicha@gmail.com
}

\begin{abstract}
Indonesia is a country that is rich in natural resources and has the potential of local food from various types of beans that have the potential to add nutrients to the diet or daily menu. One of them is cowpea, which is still a lot of people have not processed the beans optimally. So as to increase the economic value and increase the variation of processed cowpea made by cowpea juice mixed with green beans $(1: 3 ; 2: 2 ; 3: 1)$ with the addition of $C M C(0.1 \%, 0.2 \%$, $0.3 \%)$ as stabilizer. The purpose of this study was to determine the effect of CMC, the comparison of green beans and cowpea, as well as chemical and sensory characteristics. The method used was a completely randomized design (CRD) with 9 treatments of the ratio of green beans and cowpea and CMC concentration. The analysis carried out included protein levels, total sugar, and organoleptic tests. The results of the research that has been carried out that the effect of CMC on green bean juice drinks and cowpea juice showed no significant difference in organoleptic test, total sugar, and protein content.
\end{abstract}

Keywords : CMC cowpea, green beans, RTD

\section{PENDAHULUAN}

Indonesia merupakan negara yang

kaya akan sumber daya alam dan memiliki

potensi pangan lokal dari berbagai jenis

kacang-kacangan yang berpotensi untuk

menambah zat gizi dalam diet atau menu

sehari-hari. Kacang-kacangan merupakan salah satu bahan makanan sumber protein dengan nilai gizi yang tinggi $(20-25$ $\mathrm{g} / 100 \mathrm{~g}$ ), vitamin B (thiamin, riboflavin, niacin, asam folat), mineral ( $\mathrm{Ca}, \mathrm{Fe}, \mathrm{P}, \mathrm{K}$, Zn, Mg, dan lain-lain), dan serat. (Dostalova, 2009). Kacang-kacangan juga memiliki keunggulan dari segi harga yang 
murah, memiliki kandungan lemak yang baik untuk kesehatan, dan mengandung berbagai mineral yang cukup banyak (Koswara, 2013).

Salah satu kacang - kacangan yang berpotensi adalah kacang tunggak. Kacang tunggak atau kacang tolo (Vigna unguiculata, L) memiliki potensi besar sebagai bahan pangan yang bergizi sebagai bahan pengganti kacang kedelai. Pemanfaatan kacang tunggak hanya terbatas, biasanya dimanfaatkan sebagai sayuran (yaitu campuran gudeg dan lodeh), makanan tradisional (campuran lepet ketan, bubur dan bakpia) dan lauk (rempeyek), sehingga untuk meningkatkan nilai ekonomi dan menambah variasi olahan kacang tunggak dibuat sari kacang tunggak yang dicampur dengan kacang hijau ( $1: 3 ; 2: 2 ; 3: 1)$ dengan penambahan $\mathrm{CMC} \quad(0,1 \%, \quad 0,2 \%, \quad 0,3 \%) \quad$ sebagai penstabil. Kandungan protein kacang tunggak berkisar antara 18,3- 25,53\%. Keunggulan kacang tunggak adalah memiliki kadar lemak yang lebih rendah sehingga dapat meminimalisasi efek negatif dari penggunaan produk pangan berlemak. Kacang tunggak juga memiliki kandungan vitamin B1 lebih tinggi dibandingkan kacang hijau. Asam amino yang penting dari protein kacang tunggak adalah kandungan asam amino lisin, asam aspartat dan glutamat (Chavan et al., (1989) dalam Syarifah (2002)).

CMC (Carboxyl Methyl Cellulose) pada minuman mempunyai peran sebagai zat pengental. Struktur CMC (Carboxyl Methyl Cellulose) merupakan rantai polimer yang terdiri dari unit molekul sellulosa. Berdasarkan sifat dan fungsinya CMC mudah larut dalam air dingin maupun air panas (Kamal, 2010).

Minuman ready to drink (RTD) adalah istilah yang digunakan untuk mendeskripsikan jenis minuman yang dijual dalam sebuah kemasan khusus sehingga dapat langsung dikonsumsi tanpa harus diolah lebih lanjut. Dengan adanya inovasi minuman RTD sari kacang tunggak dan kacang hijau diharapkan dapat 
diterima oleh konsumen. Tujuan dalam penelitian ini yaitu untuk mengetahui pengaruh $\mathrm{CMC}$, perbandingan kacang hijau dan kacang tunggak, serta karakteristik fisik, kimia dan sensoris minuman sari kacang tunggak dan kacang hijau.

\section{BAHAN DAN METODE}

Penelitian ini dilaksanakan dengan menggunakan bahan dasar kacang tunggak dan kacang hijau yang didapatkan di Pasar Peterongan Semarang. Bahan tambahan yang digunakan adalah air, gula, garam, vanilli, sari jahe, dan CMC. Bahan yang digunakan untuk analisis yaitu aquadest, anthrone, $\mathrm{H}_{2} \mathrm{SO}_{4}, \quad$ D-glucose, tablet Kjeldahl, $\mathrm{NaOH}$, indikator PP.

Peralatan yang digunakan yaitu baskom, sendok, blender, kain saring, panci, kompor gas, pengaduk kayu, termometer, gelas, timbangan digital, timbangan analitik dan gelas ukur. Sedangkan peralatan yang digunakan untuk analisis total gula dan protein meliputi gelas beaker, labu takar $50 \mathrm{ml}$, labu takar $20 \mathrm{ml}$, pipet $10 \mathrm{ml}$, pipet $5 \mathrm{ml}$, mikro pipet, tabung reaksi, rak kayu, spektrofotometer, waterbath, labu Kjeldahl, alat Kjeldahl, corong kaca, spatula, buret, dan erlenmeyer.

Penelitian ini dilakukan secara eksperimental dengan Rancangan Acak Lengkap. Terdapat 9 perlakuan yang merupakan kombinasi rasio kacang hijau dan kacang tunggak serta konsentrasi CMC. Masing - masing perlakuan diulang 2 kali (Tabel 1). Analisis yang dilakukan yaitu meliputi kadar protein, total gula dan uji organoleptik.

Tabel 1. Rancangan Percobaan

\begin{tabular}{cccc}
\hline Rasio Kacang Hijau : & \multicolumn{3}{c}{ Konsentrasi CMC (\%) } \\
\cline { 2 - 4 } Kacang Tunggak & $\mathbf{0 , 1 \% ( A 1 )}$ & $\mathbf{0 , 2 \%}(\mathbf{A 2})$ & $\mathbf{0 , 3 \%}(\mathrm{A3})$ \\
\hline $1: 3(\mathrm{~B} 1)$ & $\mathrm{A} 1 \mathrm{~B} 1$ & $\mathrm{~A} 2 \mathrm{~B} 1$ & A3B1 \\
$2: 2(\mathrm{~B} 2)$ & $\mathrm{A} 1 \mathrm{~B} 2$ & $\mathrm{~A} 2 \mathrm{~B} 2$ & A3B2 \\
$3: 1(\mathrm{~B} 3)$ & $\mathrm{A} 1 \mathrm{~B} 3$ & $\mathrm{~A} 2 \mathrm{~B} 3$ & A3B3 \\
\hline
\end{tabular}


Prosedur pembuatan sari kacang hijau dan kacang tunggak yaitu masingmasing kacang disortasi kemudian dicuci lalu dilakukan perendaman selama 2 jam. Setelah 2 jam masing-masing kacang direbus sampai matang. Setelah matang kacang ditimbang lalu dihancurkan dengan blender sampai halus. Kemudian, dilakukan penyaringan untuk mendapatkan sari dari kacang. Sari yang didapatkan ditambah dengan CMC lalu dimasak dan ditambahkan bahan-bahan lain yaitu gula, garam, vanilli, dan sari jahe sampai suhu mencapai suhu pasteurusasi $\left(70^{\circ} \mathrm{C}\right)$ kemudian direbus sampai mendidih.

Data dianalisis dengan menggunakan Analisis Keragaman (ANOVA) faktorial. Apabila terdapat perbedaan maka dilanjutkan dengan Uji DMRT dengan taraf kepercayaan 95\%, Analisis data dengan menggunakan bantuan software computer SPSS 16.

\section{HASIL DAN PEMBAHASAN}

\section{Uji Organoleptik}

\section{Deskriptif}

Berdasarkan Tabel 2 uji organoleptik "deskriptif" menunjukkan bahwa tingkat kekentalan perlakuan sampel minuman sari kacang hijau dan kacang tunggak perbandingan 1:3 dengan konsentrasi $\mathrm{CMC} \quad 0,1 \% ; 0,2 \% ; 0,3 \%$, perbandingan 2:2 dengan CMC 0,1\%; 0,3\%, serta perbandingan 3:1 dengan CMC $0,2 \% ; 0,3 \%$ tidak berbeda nyata tetapi berbeda nyata dengan perbandingan 2:2 CMC $\quad 0,2 \%$ dan perbandingan $3: 1$ konsentrasi $\quad$ CMC $\quad 0,1 \%$. Tingkat kekentalan sari berkaitan dengan konsentrasi $\mathrm{CMC}$, semakin tinggi konsentrasi CMC yang ditambahkan maka tingkat kekentalan semakin meningkat yang dihasilkan. CMC mudah larut dalam air panas maupun air dingin. Pengurangan tingkat kekentalan dapat terjadi pada saat pemanasan yang bersifat reversibel (Sayuti, 2016). 
Tabel 2. Uji Organoleptik "Deskriptif"

\begin{tabular}{|c|c|c|c|c|}
\hline \multicolumn{2}{|c|}{ Perlakuan } & \multicolumn{3}{|c|}{ Uji Organoleptik "Deskriptif" } \\
\hline & & Kekentalan & Kemanisan & Kecerahan \\
\hline \multirow[t]{3}{*}{$1: 3$} & $0,1 \%$ & $3.00 \pm 1.01^{\mathrm{bc}}$ & $3.40 \pm 0.72^{\mathrm{bcd}}$ & $2.67 \pm 1.07^{\mathrm{a}}$ \\
\hline & $0,2 \%$ & $2.63 \pm 0.92^{b}$ & $3.23 \pm 0.89^{b c}$ & $2.80 \pm 0.92^{\mathrm{a}}$ \\
\hline & $\mathbf{0 , 3 \%}$ & $2.60 \pm 0.93^{b}$ & $3.06 \pm 0.63^{b}$ & $2.83 \pm 0.95^{\mathrm{a}}$ \\
\hline \multirow[t]{3}{*}{$2: 2$} & $0,1 \%$ & $2.60 \pm 0.77^{\mathrm{b}}$ & $3.10 \pm 0.80^{b}$ & $3.50 \pm 0.82^{b}$ \\
\hline & $0,2 \%$ & $2.13 \pm 0.62^{\mathrm{a}}$ & $2.46 \pm 0.93^{\mathrm{a}}$ & $3.36 \pm 1.03^{b}$ \\
\hline & $0,3 \%$ & $2.53 \pm 0.73^{\mathrm{ab}}$ & $3.26 \pm 0.73^{b c}$ & $3.40 \pm 0.81^{\mathrm{b}}$ \\
\hline \multirow[t]{3}{*}{ 3:1 } & $0,1 \%$ & $3.13 \pm 0.73^{c}$ & $3.60 \pm 0.81^{\mathrm{cd}}$ & $2.80 \pm 0.96^{\mathrm{a}}$ \\
\hline & $0,2 \%$ & $2.67 \pm 0.71^{\mathrm{b}}$ & $3.46 \pm 0.89^{b c d}$ & $3.03 \pm 0.71^{\mathrm{ab}}$ \\
\hline & $0,3 \%$ & $2.93 \pm 0.82^{\mathrm{bc}}$ & $3.73 \pm 0.63^{\mathrm{d}}$ & $3.00 \pm 0.79^{a b}$ \\
\hline
\end{tabular}

Keterangan :

Skala $($ Kekentalan $)=1$ : Sangat Tidak Kental, 2: Tidak Kental, 3: Agak Kental, 4:

Kental, 5: Sangat Kental

Skala $($ Kemanisan $)=1:$ Sangat Tidak Manis, 2: Tidak Manis, 3: Agak Manis, 4:

Manis, 5: Sangat Manis

Skala $($ Kecerahan $)=1$ : Sangat Tidak Cerah, 2: Tidak Cerah, 3: Agak Cerah, 4: Cerah, 5: Sangat Cerah

Tingkat kemanisan pada

perbandingan 1:3 dengan CMC $0,1 \%$ dan

3:1 CMC $0,2 \%$ tidak berbeda nyata.

Perbandingan $1: 3$ CMC $0,2 \%$ dan $2: 2$

CMC $0,3 \%$ juga tidak berbeda nyata.

Perbandingan 1:3 CMC 0,3\% dan 2:2

CMC $0,1 \%$ tidak berbeda nyata tetapi

berbeda nyata dengan perbandingan 2:2

CMC $\quad 0,2 \%$ dan $3: 1 \quad$ CMC $\quad 0,3 \%$.

Perbandingan $\quad 3: 1 \quad$ CMC $\quad 0,1 \%$ tidak berbeda nyata dengan perbandingan 1:3

CMC 0,1\% dan 0,2;3:1 CMC 0,2\%; 2:2

CMC 0,3\%; 3:1 CMC 0,3\% tetapi berbeda

nyata dengan perbandingan 2:2 CMC

0,2\%. CMC merupakan turunan selulosa yang mudah larut dalam air. Oleh karena itu CMC mudah dihidrolisis menjadi gula - gula sederhana (Masfufatun, 2010).

Tingkat kecerahan pada perbandingan 1:3 dengan konsentrasi CMC $0,1 \% ; 0,2 \% ; 0,3 \%$ tidak berbeda nyata dengan $3: 1$ CMC $0,1 \% ; 0,2 \% ; 0,3 \%$ tetapi berbeda nyata dengan 2:2 CMC $0,1 \%$; $0,2 \% ; 0,3 \%$. Perbandingan $2: 2$ dengan CMC $0,1 \% ; 0,2 \% ; 0,3 \%$ tidak berbeda nyata dengan $3: 1$ CMC $0,2 \%$ dan $0,3 \%$. Semakin banyak CMC yang ditambahkan maka nilai kecerahan akan semakin tinggi. Hal ini dikarenakan CMC mempunyai kemampuan sebagai zat penegmulsi yang 
hidrofilik mampu mengikat air, sehingga

tidak terjadi endapan. Selain itu CMC juga

sebagai penjernih larutan, sehingga sampel

yang dihasilkan mempunyai warna yan

lebih cerah (Siskawardani et al., 2013).

\section{Hedonik}

Berdasarkan Tabel 3. uji organoleptik "hedonik" menunjukkan parameter flavor sari kacang tunggak: kacang hijau pada perlakuan 1:3 dengan

CMC $0,1 \% ; 0,2 \% ; 0,3 \%$ tidak berbeda nyata dengan perlakuan 2:2 pada CMC $0,2 \% ; 0,3 \%$ dan perlakuan 3:1 dengan konsentrasi $\mathrm{CMC} \quad 0,1 \% ; 0,2 \% ; 0,3 \%$. Tetapi perlakuan 1:3 dengan CMC 0,3\% berbeda nyata dengan perlakuan 2:2 CMC $0,1 \%$.

Tabel 3. Uji Orgnaoleptik Hedonik

\begin{tabular}{cccccc}
\hline \multirow{2}{*}{ Perlakuan } & \multicolumn{4}{c}{ Uji Organoleptik "Hedonik" } \\
\cline { 2 - 6 } & & \multicolumn{1}{c}{ Flavor } & Aroma & \multicolumn{1}{c}{ Rasa } & Warna \\
\hline $\mathbf{1 : 3}$ & $\mathbf{0 , 1 \%}$ & $3.63 \pm 0.93^{\mathrm{b}}$ & $3.60 \pm 0.72^{\mathrm{b}}$ & $3.73 \pm 0.78^{\mathrm{c}}$ & $3.10 \pm 0.95^{\mathrm{ab}}$ \\
& $\mathbf{0 , 2 \%}$ & $3.40 \pm 0.81^{\mathrm{b}}$ & $3.06 \pm 0.78^{\mathrm{a}}$ & $3.06 \pm 0.86^{\mathrm{ab}}$ & $2.93 \pm 0.90^{\mathrm{a}}$ \\
& $\mathbf{0 , 3 \%}$ & $3.33 \pm 0.60^{\mathrm{ab}}$ & $3.63 \pm 0.88^{\mathrm{b}}$ & $3.30 \pm 0.74^{\mathrm{bc}}$ & $3.10 \pm 0.75^{\mathrm{ab}}$ \\
$\mathbf{2 : 2}$ & $\mathbf{0 , 1 \%}$ & $3.56 \pm 0.67^{\mathrm{a}}$ & $3.36 \pm 0.66^{\mathrm{bc}}$ & $3.26 \pm 0.69^{\mathrm{bc}}$ & $3.36 \pm 0.88^{\mathrm{ab}}$ \\
& $\mathbf{0 , 2 \%}$ & $2.93 \pm 1.01^{\mathrm{b}}$ & $3.10 \pm 0.88^{\mathrm{b}}$ & $2.70 \pm 0.95^{\mathrm{a}}$ & $3.06 \pm 0.94^{\mathrm{ab}}$ \\
& $\mathbf{0 , 3 \%}$ & $3.63 \pm 0.61^{\mathrm{b}}$ & $3.46 \pm 0.62^{\mathrm{bc}}$ & $3.36 \pm 0.76^{\mathrm{bc}}$ & $3.50 \pm 0.77^{\mathrm{b}}$ \\
$\mathbf{3 : 1}$ & $\mathbf{0 , 1 \%}$ & $3.53 \pm 0.86^{\mathrm{b}}$ & $3.46 \pm 0.77^{\mathrm{bc}}$ & $3.60 \pm 0.81^{\mathrm{c}}$ & $3.26 \pm 0.69^{\mathrm{ab}}$ \\
& $\mathbf{0 , 2 \%}$ & $3.56 \pm 0.81^{\mathrm{b}}$ & $3.50 \pm 0.97^{\mathrm{bc}}$ & $3.40 \pm 0.85^{\mathrm{bc}}$ & $3.40 \pm 0.67^{\mathrm{ab}}$ \\
& $\mathbf{0 , 3 \%}$ & $3.63 \pm 0.80^{\mathrm{b}}$ & $3.80 \pm 0.71^{\mathrm{b}}$ & $3.70 \pm 0.87^{\mathrm{c}}$ & $3.26 \pm 0.6^{\mathrm{ab}}$ \\
\hline
\end{tabular}

Skala $=1:$ Sangat Tidak Suka, 2: Tidak Suka, 3: Agak Suka, 4: Suka, 5: Sangat Suka

Parameter aroma menunjukkan

bahwa perlakuan 1:3 dengan CMC $0,1 \%$;

0,3\%, perlakuan 2:2 dengan CMC $0,1 \%$;

$0,2 \% ; 0,3 \%$ dan perlakuan 3:1 dengan

CMC $0,1 \% ; 0,2 \% ; 0,3 \%$ berbeda nyata dengan perlakuan 1:3 pada konsentrasi $0,2 \%$.

Parameter rasa menunjukkan bahwa perlakuan 1:3 dengan CMC $0,1 \%$ dan perlakuan 3:1 CMC 0,1\%; 0,3\% tidak berbeda nyata terhadap perlakuan 1:3 CMC 0,3\%, perlakuan 2:2 CMC 0,1\%; 0,3\%, dan perlakuan 3:1 CMC 0,2\% Sedangkan, perlakuan 1:3 CMC $0,2 \%$ berbeda nyata terhadap perlakuan 2:2 CMC 0,2\% serta tidak berbeda nyata pada perlakuan 1:3 CMC $0,3 \%$, perlakuan 2:2 
CMC 0,1\%; 0,3\% dan perlakuan 3:1 CMC

$0,2 \%$.

Parameter warna menunjukkan

bahwa perlakuan 1:3 dengan konsentrasi

CMC $0,2 \%$ berbeda nyata dengan perlakuan 2:2 konsentrasi CMC $0,3 \%$ tetapi tidak berbeda nyata dengan perlakuan 1:3 konsentrasi CMC 0,1\%; $0,3 \%$, perlakuan 2:2 konsentrasi CMC $0,1 \% ; 0,2 \%$ dan perlakuan 3:1 konsentrasi CMC 0,1\%; 0,2\%; 0,3\%.

\section{Total Gula}

Berdasarkan analisis total gula menunjukkan bahwa nilai tertinggi yaitu perlakuan 1:3 dengan penambahan konsentrasi CMC 0,2\% sedangkan total gula terendah yaitu pada perlakuan 3:1 penambahan konsentrasi CMC 4,89\%. Berdasarkan hasil yang tercantum didalam Tabel 4. menunjukkan semakin tinggi penambahan konsentrasi CMC, kandungan total gula ada yang mengalami peningkatan dan ada yang mengalami penurunan.
Tabel 4. Analisis Total Gula

\begin{tabular}{ccc}
\hline \multirow{2}{*}{ Perlakuan } & \multicolumn{2}{c}{ Cotal gula (\%) } \\
\hline \multirow{2}{*}{$\mathbf{1 : 3}$} & $\mathbf{0 , 1 \%}$ & $6,43 \%$ \\
& $\mathbf{0 , 2} \%$ & $10,6 \%$ \\
& $\mathbf{0 , 3 \%}$ & $7,01 \%$ \\
$\mathbf{2}: \mathbf{2}$ & $\mathbf{0 , 1 \%}$ & $6,006 \%$ \\
& $\mathbf{0 , 2 \%}$ & $5,54 \%$ \\
& $\mathbf{0 , 3 \%}$ & $5,81 \%$ \\
$\mathbf{3 : 1}$ & $\mathbf{0 , 1 \%}$ & $6,05 \%$ \\
& $\mathbf{0 , 2} \%$ & $7,52 \%$ \\
& $\mathbf{0 , 3 \%}$ & $4,89 \%$ \\
\hline
\end{tabular}

Menurut Sopandi (2001), total gula mengalami peningkatan pada setiap penambahan konsentrasi pada jenis emulsifier CMC. CMC merupakan turunan selulosa yang mengandung gum hidrokoloid dan merupakan polisakarida yang mudah terhidrolisis sehingga dengan semakin bertambahnya CMC maka akan meningkatkan total gula. Sedangkan total gula yang mengalami penurunan disebabkan karena terjadinya reaksi hidrolisis karbohidrat yang menyebabkan mudah larut dalam air.

Menurut Kusnandar (2011), air dalam sistem pangan berperan dalam reaksi hidrolisis komponen karbohidrat. Pada reaksi hidrolisis memerlukan molekul air, dimana setiap pemutusan ikatan memerlukan satu molekul air. Hal ini 
mempengaruhi peningkatan sifat kelarutan

dalam air. Molekul gula terikat satu sama

lain melalui ikatan hidrogen. Bila sebuah

kristal gula melarut, molekul-molekul air bergabung secara ikatan hidrogen gugus polar molekul gula yang terdapat di permukaan air kristal gula tersebut. Molekul-molekul air yang mula-mula terikat pada lapisan pertama tetapi tidak bergerak selanjutnya molekul-molekul gula akhirnya dikelilingi lapisan air dan melepaskan diri dari kristal sehingga gula mudah larut dalam air (Winarno, 2004).

\section{Protein}

Analisis protein terbaik yaitu dengan konsentrasi kacang hijau : kacang tunggak yaitu $1: 3$ dengan CMC $\quad 0,1 \%$ menghasilkan kadar protein sebesar 5,74\%. Hasil ini sangat jauh di bawah kadar protein kacang tunggak utuh yaitu sebesar 18,3-25,53\% (Hardiyanti, 2011). Penurunan kadar protein ini dimungkinkan karena dengan penambahan konsentrasi CMC maka kadar protein akan menurun.

$\begin{array}{ccc}\text { Hal ini } & \text { dikarenakan } & \text { CMC } \\ \text { (carboxymethyl } & \text { cellulose }) & \text { tidak }\end{array}$
mengandung protein (Alkali et al., 2008). Atau penurunan ini karenan adanya proses pengolahan pemanasan atau perebusan, yang mana selama perebusan maka protein akan terdenaturasi sehingga pecah menjadi asam - asam amino yang lebih mudah dicerna (Blessing and Gregory, 2010).

\section{KESIMPULAN}

Berdasarkan penelitian yang telah dilakukan pengaruh CMC terhadap minuman sari kacang hijau dan sari kacang tunggak menghasilkan uji deskriptif tidak berbeda nyata sedangkan uji kesukaan terdapat pada perlakuan 1:3 dengan konsentrasi CMC 0,1\%. Total gula tertinggi yaitu perlakuan 1:3 dengan penambahan konsentrasi CMC 0,2\% sebesar $10,6 \%$ sedangkan total gula terendah yaitu pada perlakuan 3:1 penambahan konsentrasi CMC 0,3\% sebesar 4,89\%. Kadar protein pada perlakuan 1:3 penambahan konsentrasi CMC $0,1 \%$ yaitu sebesar $5,74 \%$. 


\section{UCAPAN TERIMA KASIH}

Tim Hula - hula mengucapkan

terimakasih kepada Program Studi

Teknologi Pangan Fakultas Teknik dan

Informatika Universitas PGRI Semarang

yang telah mendanai penelitian kami. Tak

lupa Bapak dan Ibu Dosen yang telah

memberikan kritik dan seran serta asisten

mata kuliah Pengembangan Produk serta

teman - teman yang telah membantu.

\section{DAFTAR PUSTAKA}

Alakali, J.S., Okankwo, T.M., dan Lordye, E.M., 2008. Effect of Stabilizer on the Physic-Chemical attributes of Thermizad Yoghurt. African Jurnal of Biotechnology, 7 (2): 153-163.

Blessing, IA. and IO. Gregory. Effect of processing on the proximate composition of the dehulled and undehulled mungbean (Vigna radiata (L.) Wilczek) Flours. Pakistan Journal of Nutrition.2010; 9 (10) : 1006-1016.

Dostalova, P. K. 2009. The Changes ofGalaktosidase during Germination and High Pressure Treament of Legume Seeds. Czech J. Food Sience, S76.

Hardiyanti, Q. 2011. Kajian Kualitas Tahu dari Kacang Tunggak dan Kedelai. (Skripsi). Surabaya: Fakultas Teknologi Industri. Universitas Pembangunan Nasional Veteran.

Kamal, N. 2010. Pengaruh Bahan Aditif CMC (Caboxyl Methyl Cellulose)
Terhadap Beberapa Parameter Pada Larutan Sukrosa. Jurnal Teknologi Vol. 1 Edisi 17.

Koswara. 2013. Kacang-kacangan Sumber

Pangan yang Kaya Serat.

http://ebookpangan.com. (12 Januari 2019).

Kusnandar, F. 2011. Kimia Pangan Komponen Makro. Penerbit Dian Rakyat, Jakarta.

Masfufatun. 2010. Isolasi dan Karakteristik Enzim Selulase. (Skripsi). Fakultas Kedokteran Universitas Wijaya Kusuma. Surabaya.

Sayuti, N,A,I. 2016. Pengaruh Carboxymethyl Celulosa Natrium Sebagai Pengental terhadap Stabilitas Sirup Temulawak (Curcuma Xantrorriza Rozb). Jurnal Kebidanan dan Kesehatan Tradisional. Vol 1 No 1 hal 1-99.

Siskawardani, D. D., Komar N., dan M. B. Hermanto. 2013. Pengaruh Konsentrasi Na-CMC (NatriumCarboximethyl Cellulose) dan Lama Sentrifugasi terhadap Sifat Fisik Kimia Minuman Asam Sari Tebu (Saccharum officinarum L.). Jurnal Bioproses Komoditas Tropis 1 (1) : 54-61.

Sopandi, B. 2001. Pengantar Kimia Koloid dan Kimia Permukaan. Universitas Gajah Mada. Yogyakarta.

Syarifah, H. 2002. Pembuatan Biskuit dari Tepung Kacang Tunggak (Vigna unguiculata L. Walp) dan Tepung Fine Bran (Kajian Proporsi Tepung dan Soda Kue Terhadap Mutu Biskuit). Skripsi. Jurusan Teknologi Hasil Pertanian. Fakultas Teknologi Pertanian. Universitas Brawijaya Malang. Malang.

Winarno, F. G. 2004. Kimia Pangan dan Gizi Edisi Kesebelas. Gramedia Pustaka Utama, Jakarta. 